\title{
EVALUASI PROGRAM PEMBELAJARAN TEACHING FACTORY DI SEKOLAH USAHA PERIKANAN MENENGAH
}

\author{
Afnan Fuadi \\ e-mail: afnanfuadi@yahoo.co.id \\ Balai Diklat Aparatur Sukamandi, Kementerian Kelautan dan Perikanan
}

Jalan Raya 2 Sukamandi Ciasem subang, Jawa Barat

\begin{abstract}
Abstrak: Penelitian ini bertujuan untuk mengevaluasi pelaksanaan Program Pembelajaran Teaching Factory di SUPM Negeri Tegal. Penelitian ini merupakan penelitian evaluasi dengan menggunakan model CIPP (Context, Input, Process, Product). Subyek utama dalam penelitian ini adalah guru pengelola Teaching Factory dan siswa kelas XII jurusan Teknologi Pengolahan Hasil Perikanan. Pengumpulan data menggunakan metode wawancara, observasi, dokumentasi dan angket yang dilakukan Januari hingga Juli 2015. Hasil penelitian ini menunjukan, implementasi program pembelajaran Teaching Factory di SUPM Negeri Tegal secara umum terlihat baik. Hal ini terlihat dari hasil evaluasi menunjukan bahwa: (a) komponen context mendapatkan kategori penilaian sangat baik, (b) komponen input mendapat kategori penilaian baik, (c) komponen process mendapat kategori penilaian sangat baik, (d) komponen product mendapat kategori penilaian baik. Peningkatkan kualitas program pembelajaran Teaching Factory dapat dilakukan dengan memperbaiki aspek yang berkategori rendah dari tiap-tiap tahapan evaluasi.
\end{abstract}

Kata-kata Kunci: Evaluasi Program, Teaching Factory, CIPP Model

\section{LEARNING PROGRAM EVALUATION OF TEACHING FACTORY AT FISHERY HIGH SCHOOL}

\begin{abstract}
The aim of this research is to evaluate the implementation of Teaching Factory Learning Program in SUPM Negeri Tegal. This research is a qualitative research using CIPP Model (Context, Input, Process, Product). The main subjects of this research were the teachesr of Teaching Factory and the students of class XII in Fish Processing Technology. The data were collected through participant observation using interview, observation, document study, and questionnaire. The research found that the implementation of the learning program Teaching Factory in SUPM Negeri Tegal are generally in good condition. This can be seen from the evaluation result that (1). Context Components show a good category; (2).Input Components show a good category; (3) Process Components show a very good category; and (4) Product Components show a good category. The quality of the Teaching Factory learning program can be improved by treating the aspects of the low category in each stage of evaluation.
\end{abstract}

Keywords: program evaluation, teaching factory, CIPP Model

\section{PENDAHULUAN}

Kritik tajam yang selalu dilontarkan oleh para pengguna lulusan lembaga pendidikan adalah kompetensi lulusan yang dihasilkan oleh lembaga pendidikan masih jauh dari standar kompetensi yang ditetapkan oleh industri. Sehingga seringkali kalangan industri masih membutuhkan biaya besar dan mengalokasikan waktu yang cukup lama untuk program training.

Menyikapi kondisi tersebut maka Direktorat Jenderal Pembinaan Sekolah Menengah Kejuruan (SMK), seperti tertuang dalam Roadmap
Pengembangan SMK 2010-2014, menyebutkan akan terus berupaya untuk memberdayakan SMK dalam menciptakan lulusan yang berjiwa wirausaha dan memiliki kompetensi keahlian melalui pengembangan kerjasama dengan industri dan berbagai entitas bisnis yang relevan dalam bentuk Teaching Industry/ Factory.

Teaching factory merupakan pembelajaran berorientasi bisnis dan produksi. Proses penerapan program teaching factory adalah dengan memadukan konsep bisnis dan pendidikan kejuruan sesuai dengan kompetensi keahlian yang relevan, misalnya pada program studi keahlian tata busana melalui kegiatan 
pembuatan dan penjualan busana yang dikerjakan oleh Peserta Didik (Kuswantoro, 2014: 22).

Salah satu sekolah kejuruan yang turut menerapkan program pembelajaran teaching factory adalah Sekolah Usaha Perikanan Menengah (SUPM) Negeri Tegal. Namun demikian, fakta empirik di lapangan menunjukan pelaksanaan program pembelajaran teaching factory tersebut belum masih terdapat berbagai kendala. Ketidaksesuaian antara kondisi nyata dan kondisi ideal dari permasalahan di atas, mendukung perlunya dilaksanakan evaluasi terhadap pelaksanaan program pembelajaran teaching factory di SUPM Negeri Tegal tersebut.

Fitzpatrick, Sanders dan Worthen (2004:5), mengatakan evaluasi sebagai berikut: "Evaluationuses inquiry and judgment methods, including: (1) determining standars for judging quality and deciding whether those standars should be relative or absolute, (2) collecting relevant information, and (3) applying the standars to determine value, quality, utility, effectiveness, or siginificance". Sesuai definisi tersebut, evaluasi merupakan suatu suatu kegiatan untuk mengidentifikasi, mengklarifikasi dan mengaplikasikan sejumlah kriteria untuk menentukan nilai atau harga dari suatu obyek yang dievaluasi.

Menurut Joint Commitee on Standars for Educational Evaluation menyatakan evaluasi program adalah: "Program evaluation that assess educational activities which provide service on a continuing basis and often involve curricular offerings." (Widyoko, 2001:9).

Sementara Sudjana (2008:21), mengartikan bahwa evaluasi program merupakan kegiatan sistematis untuk mengumpulkan, mengolah, menganalisis dan menyajikan data sebagai masukan untuk pengambilan keputusan. Dalam pengertian ini data adalah fakta, keterangan atau informasi yang darinya dapat ditarik kesimpulan.

Difinisi lain dikemukakan oleh dua orang ahli evaluasi yaitu Cronbach dan Stufflebeam, mereka mengemukakan bahwa evaluasi program adalah upaya menyediakan informasi untuk disampaikan kepada pengambil keputusan (dalam Arikunto dan Cepi, 2008:5).

Berdasarkan beberapa definisi mengenai evaluasi program di atas maka dapat disimpulkan bahwa evaluasi program merupakan sebuah cara sistematis dalam mengumpulkan, menyusun, mengolah dan kemudian menganalisa informasi, fakta dan data yang kemudian dihasilkan sebuah kesimpulan, manfaat dan keberhasilan dari suatu program yang dilaksanakan.
Bila dikaitkan dengan pembelajaran maka pengertian evaluasi program pembelajaran adalah suatu proses atau kegiatan yang sistematis, berkelanjutan dan menyeluruh dalam rangka pengendalian, penjaminan dan penetapan kualitas (nilai dan arti) pembelajaran berdasarkan pertimbangan dan kriteria tertentu (Arifin, 2013:9).

Definisi pembelajaran disebutkan oleh Heinich (1996:6) sebagai berikut: "Learning is the development of knowledge, skills, or attitudes as an individual interacts with information and the environment". The learning environment includes the physical facilities, the psychological atmosphere, instructinonal technology, media an methods." Dalam definisi tersebut pembelajaran diartikan sebagai interakasi antara seseorang terhadap infomasi dan lingkungan. Lingkungan pembelajaran meliputi fasilitas fisik, suasana psikologi, teknologi pembelajaran, media dan metodologi.

Selanjutnya, Suparman (2010:10) mengatakan bahwa pembelajaran merupakan rangkaian kegiatan yang direncanakan lebih dahulu oleh penyelenggara pendidikan atau oleh pengajar dan terarah pada hasil belajar tertentu.

Mengingat program pembelajaran teaching factory yang bersifat kompleks, meliputi berbagai aspek yang saling terkait dan sistemik, maka model evaluasi yang digunakan adalah model evaluasi CIPP (Context, Input, Process dan Product).

Menurut Stufflebeam sebagaimana dikutip oleh Tayibnafis (200:14-15), model evaluasi CIPP ditinjau dari kepentingannya dapat dibedakan menjadi empat komponen. Komponen-komponen tersebut adalah sebagai berikut. Pertama, context evaluation to serve planning decision. Konteks evaluasi ini membantu merencanakan keputusan, menentukan kebutuhan yang akan dicapai oleh program dan merumuskan tujuan program. Kedua, input evaluation structuring decision. Evaluasi ini menolong mengatur keputusan, menentukan sumber-sumber yang ada, alternatif apa yang diambil, apa rencana dan strategi untuk mencapai kebutuhan, serta bagaimana prosedur kerja untuk mencapainya. Ketiga, process evaluation to serve implementating decision. Evaluasi proses untuk membantu mengimplementasikan keputusan, sampai sejauh mana rencana telah diterapkan dan apa yang harus direvisi. Begitu pertanyaan tersebut terjawab, prosedur dapat dimonitor, dikontrol dan diperbaiki. Keempat, product evaluation to servel recycling decision. Evaluasi produk untuk menolong keputusan selanjutnya, apa hasil yang telah dicapai, dan apa yang dilakukan setelah program berjalan. 
Beberapa masalah yang akan dijawab dalam penelitian ini adalah (a) Bagaimana landasan kebijakan yang merupakan konteks (context) dari program pembelajaran teaching factory di SUPM Negeri Tegal? (b) Bagaimana kesiapan dari segi masukan (input) dalam menunjang pelaksanaan program pembelajaran teaching factory di SUPM Negeri Tegal? (c) Bagaimana proses (process) pelaksanaan program pembelajaran teaching factory di SUPM Negeri Tegal? Bagaimana pencapaian hasil (product) dari pelaksanaan program pembelajaran teaching factory di SUPM Negeri Tegal?

Sesuai dengan model evaluasi yang digunakan, maka tujuan penelitian secara rinci dijabarkan sebagai berikut. Pertama, mengevaluasi pelaksanaan pembelajaran teaching factory dari segi konteks (context), yakni: landasan kebijakan yang dijadikan acuan dalam mendukung pelaksanaan pembelajaran teaching factory, dan kebijakan Kepala Sekolah. Kedua, mengevaluasi pelaksanaan pembelajaran teaching factory dari segi masukan (input) yang meliputi: Perencanaan Kegiatan teaching factory, Kesiapan Guru, Kesiapan Peserta Didik, Sarana prasarana, dan Pembiayaan. Ketiga, mengevaluasi pelaksanaan pembelajaran teaching factory dari segi proses (process) yang meliputi: penjadwalan pembelajaran, kinerja guru, aktivitas guru dan aktivitas peserta didik.
Keempat, mengevaluasi pelaksanaan pembelajaran teaching factory dari segi produk (product) yang meliputi: hasil belajar, hasil produksi atau jasa dan pencitraan.

\section{METODE PENELITIAN}

Penelitian ini dikategorikan sebagai penelitian evaluasi. Pendekatan yg digunakan adalah kualitatif, sedangkan metode yang digunakan adalah studi kasus (case studies). Penelitian kualitatif merupakan penelitian yang bermaksud untuk memahami fenomena tentang apa yang dialami oleh subjek penelitian misalanya, perilaku, persepsi, motivasi, tindakan dan lain-lain secara holistik, dan dengan cara deskripsi dalam bentuk kata-kata dan bahasa, pada suatu konteks khusus yang alamiah dan dengan memanfaatkan berbagai metode ilmiah (Moleong, 2012:6).

Penelitian evaluasi ini menggunakan model CIPP yang dikembangkan oleh Daniel Stufflebeam. Pemilihan model evaluasi CIPP ini didasarkan pada karakteristiknya yang bersifat komprehensif, meliputi: context, input, process, dan product. Adapun desain penelitian evaluasi program pembelajaran Teaching Factory di SUPM Tegal adalah seperti pada Gambar 1.

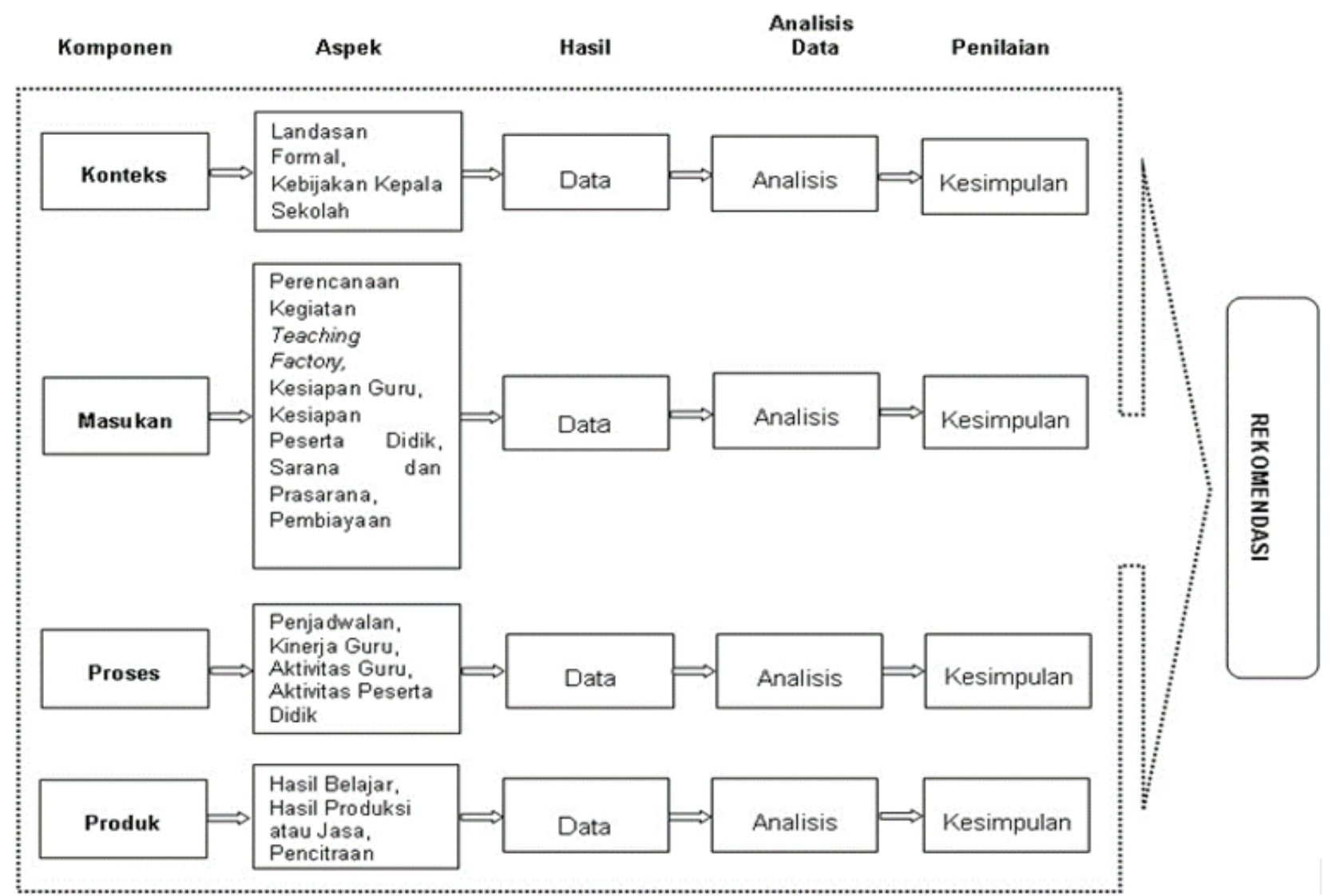

Gambar 1. Desain penelitian evaluasi 
Penelitian dilakukan pada bulan Januari hingga Juli 2015. Dalam pelaksanaan penelitian evaluasi ini, peneliti menggunakan pendekatan kualitatif dan juga menggunakan data-data kuantitatif untuk menunjang pelaksanaan analisis data. Peneliti melakukan pengumpulan data tersebut menggunakan instrumen pengumpulan data, berupa studi dokumentasi, pedoman observasi, pedoman angket dan pedoman wawancara. Berbagai sumber data yang dimanfaatkan dalam pembelajaran ini dapat dikelompokan ke dalam empat kelompok sumber data. Keempat sumber data tersebut adalah sebagai berikut: (1) Informan atau narasumber, yaitu meliputi kepala sekolah, guru dan peserta didik; (2) peristiwa atau aktivitas, yaitu berupa pelaksanaan kegiatan pembelajaran teaching factory; (3) tempat atau lokasi, yaitu berupa kondisi sekolah tempat pelaksanaan pembelajaran teaching factory, (4) arsip dan dokumen yang meliputi dokumen yang berkaitan dengan landasan kebijakan, program pembelajaran (RPP), perencanaan kegiatan dan hasil belajar teaching factoy di SUPM Negeri Tegal.

Agar keabsahan data teruji tingkat kredibilitasnya, maka dilakukan pemeriksaan keabsahan yang dilakukan dengan cara sebagai berikut. Pertama, menggunakan teknik triangulasi, yaitu merupakan cara yang paling umum yang digunakan dalam penelitian kualitiatif guna mewujudkan validitas data. Dalam penelitian ini digunakan beberapa metode pengumpul data, sehingga diharapkan akan diperoleh data yang beragam untuk pelaksanaan trianggulasi. Kedua, review informan, yaitu upaya pengembangan validitas data yang dilakukan dengan cara mengkomunikasikan unit-unit laporan yang telah disusun kepada informannya. Dengan cara ini maka laporan yang telah ditulis akan merupakan suatu deskripsi sajian yang disetujui informan dan sesuai dengan keadaan yang sebenarnya. Ketiga, menyempurnakan pedoman penelitian selama berlangsungnya kajian. Pedoman penelitian, dikoreksi dan diperbaiki sesuai dengan kenyataan lapangan yang sesungguhnya.

Analisis data yang digunakan dalam penelitian evaluasi ini adalah analisis deskriptif, yaitu dengan menggunakan dan memaknai data dari masingmasing indikator komponen konteks, input, proses dan produk yang dievaluasi. Data yang telah terkumpul dianalisis dengan melakukan beberapa langkah, yakni (1) penskoran jawaban responden, (2) menjumlahkan skor total masing-masing komponen, dan (3) mengelompokan skor yang diperoleh dari responden berdasarkan tingkat kecenderungan. Pendekatan kualtitatif terdapat dua model dalam melakukan analisis penelitian, yaitu: (1) model analisis jalinan atau mengalir (Flow Model of Analysis) dan (2) model analisis interaktif (Miles \& Hubermen, 1994:10). Sedangkan model analisis yang digunakan dalam penelitian ini adalah model analisis interaktif yang terdiri dari reduksi data, sajian data, dan penarikan kesimpulan.

\section{HASIL DAN PEMBAHASAN}

Sekolah Usaha Perikanan Menengah (SUPM) Negeri Tegal merupakan merupakan sekolah kejuruan di bidang perikanan yang berada di bawah naungan Kementerian Kelautan dan Perikanan. SUPM Negeri Tegal yang berlokasi di Jl. Martoloyo, Tegal Jawa Tengah, didirikan tahun 1962 sebagai pengembangan dari Sekolah Perikanan Laut (SPL).

Sejak tahun 2011 SUPM Negeri Tegal menerapkan pendekatan baru dalam pembelajaran yang disebut dengan model pembelajaran teaching factory. Melalui model pembelajaran tersebut diharapkan dapat memberikan pengalaman nyata bagi Peserta Didik dengan memanfaatkan unit produksi di sekolah. Berdasarkan evaluasi yang telah dilakukan, selanjutnya dapat diuraikan dalam hasil penelitian dan pembahasan sebagai berikut

\section{Komponen Konteks (Context)}

Tahapan awal peneliti terjun ke lapangan adalah melakukan analisis komponen konteks (context) program pembelajaran teaching factory terlebih dahulu. Ada dua aspek yang dianalisis dalam komponen konteks, yakni (a) landasan formal teaching factory dan (b) kebijakan kepala sekolah. Landasan Formal menyangkut dukungan peraturan yang berlaku terhadap penyelenggaraan teaching factory, sedangkan kebijakan kepala sekolah menyangkut kebijakankebijakan yang diambil pimpinan sekolah berkaitan dengan penyelenggaraan teaching factory. Selanjutnya deskripsi untuk masing-masing aspek pada komponen konteks yang menjadi fokus evaluasi diuraikan sebagai berikut:

\section{Landasan Formal Teaching Factory}

Berdasarkan penelusuran terhadap peraturanperaturan perundangan yang telah diterbitkan oleh pemerintah, dapat ditemukan berbagai peraturan perundangan yang mendukung dan selaras dengan pelaksanaan pembelajaran teaching factory sebagai berikut: Undang-undang Sistem Pendidikan Nasional (UUSPN) Nomor 20 tahun 2003 dalam penjelasan Pasal 15, disebutkan bahwa Sekolah Menengah Kejuruan "Pendidikan kejuruan adalah pendidikan menengah yang mempersiapkan Peserta Didik terutama untuk 
bekerja dalam bidang tertentu".

Selanjutnya dalam Peraturan Pemerintah Nomor 29 tahun 1990 tentang Pendidikan Menengah, sebagaimana telah diubah dengan Peraturan Pemerintah Nomor 56 Tahun 1998 tentang Perubahan atas Peraturan Pemerintah Nomor 29 Tahun 1990 tentang Pendidikan Menengah, dalam Pasal 3 juga menyebutkan bahwa, "Pendidikan menengah kejuruan mengutamakan penyiapan peserta didik untuk memasuki lapangan kerja serta mengembangkan sikap profesional".

Landasan formal yang relevan selanjutnya adalah Peraturan Menteri Pendidikan Nasional Nomor 41 Tahun 2007 tentang Standar Proses untuk Satuan Pendidikan Dasar dan Menengah. Sesuai lampiran Standar Proses tersebut, tertera dalam Romawi II, huruf B, menyebutkan bahwa Metode Pembelajaran digunakan oleh guru untuk mewujudkan suasana belajar dan proses pembelajaran agar peserta didik mencapai kompetensi dasar atau seperangkat indikator yang telah ditetapkan. Pemilihan metode pembelajaran disesuaikan dengan situasi dan kondisi peserta didik, serta karakteristik dari setiap indikator dan kompetensi yang hendak dicapai pada setiap mata pelajaran.

Sebagai sebuah pendekatan pembelajaran, maka konsep teaching factory telah sejalan dengan tuntutan Peraturan Menteri tersebut. Sebagiamana diketahui bahwa pembelajaran teaching factory merupakan metode pembelajaran yang bertujuan untuk membekali peserta didik agar memiliki kompetensi tertentu, dalam hal ini pengetahuan dan keterampilan praktis, sehingga peserta didik siap memasuki dunia usaha dan dunia industri.

Selanjutnya, landasan yang lebih spesifik terhadap penyelenggaraan teaching factory adalah diterbitkannya Keputusan Kepala Badan Pengembangan SDM Kelautan dan Perikanan, Nomor KEP.97/BPSDMKP/2011 tentang Pedoman Pelaksanaan Teaching Factory Pada Sekolah Usaha Perikanan Menengah di Lingkungan Kementerian Kelautan dan Perikanan. Pedoman tersebut merupakan acuan pembelajaran teaching factory pada Sekolah Usaha Perikanan Menengah. Dengan diterbitkannya Keputusan tersebut maka landasan kebijakan pelaksanaan teaching factory di SUPM Negeri Tegal telah cukup kuat.

Berdasarkan analisis dokumen terhadap aspek landasan formal pelaksanaan teaching factory, dapat dikatakan bahwa pelaksanaan teaching factory di SUPM Negeri Tegal telah didukung sekaligus selaras dengan perangkat peraturan-peraturan perundangan yang ada. Hasil penilaian aspek landasan formal mendapatkan skor 5 dari skor ideal 5 dengan perolehan persentase maksimum sebesar $100 \%$. Berdasarkan hasil evaluasi tersebut maka dapat dikatakan aspek landasan formal mendapat kategori penilaian sangat baik.

2. Kebijakan Kepala Sekolah

Berdasarkan hasil wawancara yang telah dilakukan dengan Kepala SUPM Negeri Tegal, diperoleh penjelasan bahwa pelaksanaan pembelajaran teaching factory ini sangat sesuai dari segi karakteristik SUPM yang merupakan sekolah kejuruan. Kebijakan teaching factory ini juga sejalan dengan visi SUPM yakni: "Menghasilkan sumberdaya manusia kelautan dan perikanan tingkat menengah yang kompeten dan berjiwa wirausaha".

Kebijakan yang telah diambil oleh Kepala SUPM Negeri Tegal adalah menjalin kerjasama dengan berbagai pihak, yang salah satunnya kerjasama dengan PT. Makanan Sehat Nusantara dalam proses pembuatan Surimi. Melalui kerjasama tersebut, perusahaan menyediakan bahan baku untuk produksi, sedangkan sekolah menyediakan sarana sekaligus tenaga kerjanya.

SUPM Negeri Tegal juga telah menyusun struktur organisasi teaching factory pengolahan ikan. Struktur organisasi tersebut, dipimpin oleh pengadministrasi sarpras instalasi TEFA yang dibantu oleh pengelola pemasaran produk kemitraan, kendali mutu produksi dan pengelola pengendali standar keselamatan kerja, pengelola utilitas gedung TEFA.

Namun demikian, sampai saat ini SUPM Negeri Tegal belum menerbitkan petunjuk teknis program pembelajaran teaching factory. SUPM Negeri Tegal hanya berpedoman pada pedoman pelaksanaan pembelajaran teaching factory yang telah diterbitkan oleh Kepala Badan Pengembangan SDM Kelautan dan Perikanan.

Berdasarkan hasil penilaian menggunakan rubrik penilaian hasil evaluasi, aspek kebijakan Kepala Sekolah memperoleh jumlah skor 24 dari skor ideal 30 dengan persentase sebesar $80 \%$, sehingga masuk dalam kategori penilaian baik.

Sedangkan hasil penilaian komponen konteks secara keseluruhan komponen konteks diperoleh persentase sebesar $90 \%$ atau mendapat deskrpisi sangat baik.

\section{Komponen Masukan (Input)}

Komponen masukan mencakup analisis persoalan yang berhubungan dengan penggunaan sumberdaya yang tersedia dan alternatif strategi yang dikembangkan untuk mencapai program. Ada lima 
aspek yang dianalisis dalam komponen masukan, yakni: (a) perencanaan kegiatan teaching factory, (b) kesiapan guru, (c) kesiapan peserta didik, (d) sarana prasarana, dan (e) pembiayaan. Deskripsi untuk masing-masing aspek pada komponen masukan yang menjadi fokus evaluasi diuraikan sebagai berikut.

\section{Perencanaan Kegiatan Teaching Factory}

Berdasarkan studi dokumen dan wawancara yang telah dilakukan dengan kepala sekolah dan para guru, diperoleh informasi bahwa mengenai perencanaan kegiatan dalam satu tahun, sampai saat ini SUPM belum menyusun dalam rencana kerja tahunan yang spesifik untuk program teaching factory. Namun demikian SUPM Negeri Tegal telah menyusun Program Kerja Tahunan SUPM secara umum, yang salah satu di dalamnya mencantumkan pelaksanaan program teaching factory.

Selanjutnya, menurut keterangan yang disampaikan sekretaris dewan guru, program pembelajaran teaching factory juga belum terdapat perencanaan untuk jangka menengah dan jangka panjang.

Berdasarkan penilaian terhadap aspek Perencanaan Kegiatan teaching factory di SUPM Negeri Tegal diperoleh skor 5 dari skor ideal 15 dengan hasil persentase sebesar 33\% atau mendapat kategori penilaian kurang.

\section{Kesiapan Guru}

Aspek kesiapan guru di telusuri melalui angket yang diberikan kepada semua guru pengampu pembelajaran teaching factory pengolahan ikan yang berjumlah empat orang denga pertanyaan meliputi, tingkat pendidikan, kesesuaian mengajar dengan ijazah, pengalaman mengajar, pengalaman mengajar, magang, training, dan studi banding. Berdasarkan angket yang diberikan kepada guru tersebut diperoleh informasi bahwa, semua guru telah berpendidikan S1/ DIV (Sarjana). Selanjutnya, semua guru tersebut telah mengajar sesuai dengan latar belakang pendidikannya, yakni pengolahan ikan. Mengenai pengalaman mengajar, diperoleh data bahwa seluruh guru telah memiliki pengalaman mengajar lebih dari dua tahun.

Di samping memiliki pengalaman mengajar yang cukup, semua guru juga telah memiliki pengalaman magang di dunia industri sesuai dengan bidang keahlian yang diajarkan. Namun demikian, hasil penilaian angket untuk unsur pengalaman guru mengikuti training pengelolaan pembelajaran teaching factory memperoleh skor $0 \%$. Dengan demikian dapat dikatakan bahwa semua guru belum pernah diberikan pelatihan tentang pengelolaan pembelajaran teaching factory. Selanjutnya untuk pertanyaan terakhir, tentang pengalaman melakukan studi banding pelaksanaan pembelajaran teaching factory, dari empat orang guru, hanya dua orang yang menyatakan pernah melakukan studi banding pembelajaran teaching factory, sedangkan dua guru yang lain menyatakan belum pernah melaksanakan studi banding pembelajaran teaching factory di satuan pendidikan yang lain.

Setelah dinilai menggunakan rubrik evaluasi maka didapatkan skor aspek kesiapan guru yang diperoleh berjumlah 24 dari skor ideal yang diharapkan 30 , atau memperoleh persentase sebesar $80 \%$, dengan kategori penilaian baik.

3. Kesiapan Peserta Didik

Aspek kesiapan peserta didik dalam melaksankan program pembelajaran teaching factory menggunakan dua indikator, yakni peserta didik telah dibekali materi kewirausahaan dan peserta didik telah dibekali pengetahuan awal proses produksi.

Peserta didik yang menjadi responden dalam penelitian ini adalah seluruh peserta didik SUPM Negeri Tegal kelas XII (kelas tiga) program keahlian teknologi pengolahan hasil perikanan yang berjumlah 33 orang. Alasan diambilnya peserta didik dari kelas xii tersebut sebagai responden, dengan pertimbangan karena mereka telah mengikuti semua materi pembelajaran secara tuntas. Berdasarkan angket yang diberikan kepada responden menunjukan untuk pertanyaan pertama tentang apakah peserta didik telah dibekali materi kewirausahaan sebelum mengikuti program pembelajaran teaching factory, semua peserta didik memilih jawaban "ya". Selanjutnya dengan pertanyaan kedua, tentang apakah peserta didik telah dibekali pengetahuan awal proses produksi, semua peserta didik juga memberikan jawaban "Ya". Dengan perolehan jawaban yang demikian maka dapat diindikasikan bahwa kedua indikator terkait penyiapan peserta didik dalam mengikuti pembelajaran teaching factory di SUPM Negeri Tegal telah benar-benar dilaksanakan dengan baik.

Selanjutnya skor yang diperoleh untuk aspek kesiapan peserta didik memperoleh skor 10 dari skor ideal yang diharapkan 10, atau memperoleh persentase maksimlal sebesar $100 \%$. Dengan perolehan persentase tersebut maka aspek kesiapan peserta didik mendapat kategori penilaian sangat baik.

4. Sarana dan Prasarana

Beberapa indikator yang digunakan untuk menilai bangunan/ruang teaching factory dalam penelitian ini antara lain: status bangunan, lokasi bangunan terhadap ruangan lainnya, luas bangunan, penggunaan bagunan dan kondisi bangunan. Sedangkan untuk menilai perlengkapan unit produksi 
digunakan beberapa indikator yang terdiri dari: peralatan produksi, jaringan listrik, meja/kursi kerja peserta didik, meja demonstrasi guru, papan tulis, spidol, penghapus, lemari/rak tempat peralatan, pedoman kerja/tata tertib, papan informasi dan pemadam kebakaran.

Berdasarkan hasil observasi di lapangan menggunakan inventory checklist diperoleh informasi bahwa, status bangunan gedung teaching factory adalah milik SUPM Negeri Tegal sendiri. Terdapat dua buah bangunan gedung teaching factory pengolahan, yakni: satu gedung untuk pengolahan produk fish jelly (produk olahan ikan siap saji), dan satu bangunan dipergunakan untuk pengolahan produk surimi (lumatan daging Ikan). Selanjutnya dapat digambarkan bahwa di dalam bangunan terdapat beberapa ruang dengan fungsi yang berbeda antara lain: ruang produksi, ruang administrasi, dan ruang briefing dan toliet yang terdapat di sisi bangunan. Bangunan untuk pengolahan surimi terdiri dari dua lantai, dengan penggunaan lantai satu untuk produksi dan lantai dua untuk kelas. Jarak antara gedung teaching factory dengan ruang kantor SUPM terpisah jauh sehingga keberadaannya tidak akan mengganggu aktivitas kerja. Dengan menempati luas tanah sekitar $500 \mathrm{~m}^{2}$, maka dari segi luas bangunan dapat dikatakan luas bangunan telah memadai. Dari sisi penggunaan, bangunan telah khusus digunakan untuk pembelajaran teaching factory, tidak digunakan untuk kegiatan-kegiatan yang lain. Struktur bangunan stabil dan kokoh dan ventilasi dan pencahayaan juga memadai. Namun demikian masih terdapat kekurangan yang peneliti dapatkan, yakni rusaknya pintu-pintu toilet dan tidak dapat dikunci.

Selanjutnya berdasarkan hasil observasi yang telah dilakukan terhadap ketersediaan perlengkapan teaching factory menunjukan bahwa sebagian besar perlengkapan teaching factory sudah tersedia dan dapat dalam kegiatan pembelajaran di Sekolah. Namun demikian, masih ada yang dirasakan kurang oleh guru dan peserta didik sehingga masih perlu diadakan, yakni kebutuhan ketersediaan cold storage (mesin penyimpan produk), contact plate freezer (mesin pembeku). Kemudian untuk leaching tank (mesin pencucian daging) sudah tersedia namun baru tardapat satu buah dari kebutuhan yang diperlukan dua buah. Selanjutnya untuk perlengkapan yang lain secara umum sudah tersedia dan lengkap, seperti jaringan listrik sudah cukup memadai, meja kerja untuk peserta didik, meja demonstrasi guru, papan tulis, spidol dan penghapus tersedia, lemari/rak menyimpan peralatan, pedoman kerja/tata tertib, papan informasi juga sudah tersedia. Hanya ada satu perlengkapan dari 14 perlengkapan yang dinilai tidak tersedia, yakni tabung pemadam kebakaran.

Berdasarkan hasil evaluasi maka dapat disimpulkan bahwa secara umum aspek sarana dan prasarana telah memadai, meskipun masih terdapat beberapa kekurangan ataupun kerusakan sarana yang harus diperbaiki. Setelah hasil evaluasi dinilai menggunakan rubrik penilaian hasil evaluasi diperoleh skor total 33 dari skor ideal 42, atau memperoleh persentase $79 \%$, sehingga mendapat kategori penilaian baik.

5. Pembiayaan

Berdasarkan informasi yang terhimpun dari hasil beberapa indikator yang digunakan untuk menilai aspek pembiayaan dalam pelaksanaan teaching factory di supm negeri tegal antara lain: (a) apakah terdapat modal kerja tetap untuk melaksanakan kegiatan usaha atau produksi, (b) apakah telah terdapat biaya untuk peningkatan kapasitas untuk guru teaching factory, (c) apakah telah diberikan insentif bagi guru, dan (d) apakah tersedia biaya penunjang pembelajaran teaching factory.

Berdasarkan studi dokumentasi dan hasil wawancara diperoleh informasi bahwa, modal kerja tetap kegiatan produksi telah tersedia, khususnya untuk pegolahan produk fish jelly (produk olahan ikan siap saji). Meskipun besaran modal masih terbatas, namun tidak dirasakan sebagai masalah dan sudah dapat digunakan untuk menjalankan kegiatan produksi di teaching factory.

Kemudian untuk ketersediaan biaya peningkatan kapasitas guru teaching factory, berdasarkan penjelasan kepala sekolah bahwa, pihak sekolah telah menyediakan biaya tersebut, namun ketersediaan dana masih terbatas dan sifatnya umum, belum ada alokasi khusus untuk teaching factory. artinya setiap kegiatan peningkatan kapasitas guru, untuk pemberangkatan pelatihan, magang, seminar dan lain-lain, dapat diambilkan dari anggaran tersebut. dengan demikian maka unsur ketersediaan biaya untuk program peningkatan kapasitas guru telah disediakan oleh sekolah hanya saja belum spesifik ditujukan untuk program pembelajaran teaching factory.

Selanjutnya penelusuran dilakukan untuk memperoleh informasi ketersediaan insetif bagi guru pengelola teaching factory, berupa honor yang diberikan di luar gaji. Berdasarkan hasil studi dokumentasi dan wawancara diperoleh informasi bahwa hal tersebut belum tersedia. Menurut penjelasan salah seorang guru bahwa untuk pemberian tambahan penghasilan 
untuk guru yang mengajar teaching factory belum dapat dilakukan karena terkendala aturan.

Selanjutnya, evaluasi dilakukan terhadap ketersediaan biaya penunjang pembelajaran teaching factory, dalam hal ini adalah segala biaya yang diperlukan untuk menunjang kegiatan pembelajaran seperti pembelian buku, CD ataupun alat peraga. Seperti di jelaskan oleh guru bahwa segala kebutuhan tersebut telah terdapat dalam anggaran rutin sekolah yang berlaku untuk semua kegiatan pembelajaran termasuk untuk kegiatan teaching factory.

Dengan demikian maka dapat dikatakan bahwa unsur ketersediaan biaya penunjang pembelajaran teaching factory, selama ini tidak terdapat masalah, telah tersedia dan cukup. Selanjutnya, berdasarkan penghitungan menggunakan rubrik penilaian hasil evaluasi terhadap semua unsur-unsur aspek pembiayaan diperoleh skor total aspek pembiayaan hanya 10 dari total skor ideal 20, atau hanya memperoleh $50 \%$, dengan kategori penilaian cukup.

Hasil penilaian terhadap seluruh aspek yang terdapat di dalam komponen masukan kemudian disatukan untuk memperoleh hasil evaluasi komponen masukan secara keseluruhan. Setelah dilakukan perhitungan maka diperoleh hasil persentase untuk evaluasi komponen masukan sebesar 78\%, sehingga masuk dalam kategori penilaian baik.

Berdasarkan analisis data terhadap lima aspek yang terdapat di dalam komponen masukan maka dapat disimpulkan bahwa komponen masukan program pembelajaran teaching factory di SUPM Negeri Tegal secara keseluruhan memperoleh persentase sebesar $68 \%$ atau mendapat kategori penilaian baik.

\section{Komponen Proses (Process)}

Komponen proses mencakup analisis persoalan yang diarahkan untuk mendeteksi seberapa jauh program pembelajaran teaching factory di SUPM Negeri Tegal yang dilaksanakan sudah terlaksana sesuai dengan rencana. Ada empat aspek yang dianalisis dalam komponen proses, yakni: (a) penjadwalan pembelajaran, (b) kinerja guru, (c) aktivitas guru, dan (d) aktivitas peserta didik.

1. Penjadwalan

Indikator pertama yang digunakan untuk menilai aspek penjadwalan adalah, apakah penjadwalan yang diterapkan sudah memenuhi prinsip pembelajaran tuntas. Berdasarkan angket yang diberikan kepada guru sebagai responden, menunjukan persentase skor untuk pertanyaan ini memperolah hasil yang maksimal sebesar $100 \%$. Berdasarkan skor tersebut berarti, menurut para guru prinsip pembelajaran tuntas telah terlaksana dengan sangat baik. Selanjutnya peneliti menelusuri lebih lanjut bagaimana mekanisme panjadwalan yang telah dilakukan melalui wawancara dan observasi secara langsung. Berdasarkan hasil wawancara dengan salah seorang guru, menjelaskan bahwa, prinsip pembelajaran tuntas telah terakomodir dengan baik dalam pembelajaran teaching factory. Semua materi diberikan secara utuh, mulai dari persiapan bahan, proses produksi, pengemasan, bahkan sampai pemasaran.

Selanjutnya evaluasi dilakukan untuk melihat sejauh mana sinkronisasi penjadwalan pembelajaran teaching factory dengan pembelajaran lain di kelas. Berdasarkan angket yang diberikan kepada Guru menunjukan bahwa, terhadap pertanyaan terkait indikator sinkronisasi penjadwalan pembelajaran mendapat persentase skor sebesar 50\%. Hal tersebut menunjukan bahwa dari empat responden Guru yang memberikan jawaban, ada dua orang menjawab "Ya" dan dua orang menjawab "Tidak".

Jawaban yang berbeda terhadap pertanyaan yang sama tersebut pada awalanya membuat peneliti kesulitan melakukan intrepretasi. Namun setelah peneliti melakukan penelusuran lebih lanjut melalui wawancara, akhirnya peneliti dapat memperoleh informasi dengan lebih jelas. Berdasarkan penjelasan yang diberikan salah seorang guru mengatakan bahwa, selama ini semua kegiatan pembelajaran di sekolah dapat berjalan bersama, baik kegiatan pembelajaran di kelas dan maupun kegiatan produksi melalui teaching factory. Hal tersebut yang menjadikan dasar bagi yang bersangkutan sehingga memberikan jawaban "Ya". Namun demikian ketika peneliti bertanya lebih lanjut kepada responden Guru yang lain, peneliti mendapatkan penjelasan yang sedikit berbeda. Berdasarkan keterangan guru tersebut bahwa sinkronisasi penjadwalan teaching factory dan pembelajaran di kelas memang telah dilakukan namun masih terdapat kekurangan dalam penerapannya. Hal tersebut dikarenakan sinkronisasi penjadwalan yang selama ini dilakukan dengan menggunakan sistem piket. Caranya adalah, setiap hari telah ditentukan jadwal piket kepada sejumlah peserta didik untuk bertugas di unit produksi teaching factory. Sementara peserta didik yang tidak mendapat jadwal piket teaching factory tetap belajar di kelas sesuai mata pelajaran pada hari tersebut. Konsekuensi dari sistem tersebut menyebabkan sejumlah peserta didik tidak dapat mengikuti pembelajaran di kelas dikarenakan harus bertugas di unit produksi teaching factory pada hari tersebut. Hal inilah yang menjadi dasar bagi guru yang berangkutan sehingga memilih jawaban "Tidak" 
atau memberikan penilaian bahwa sinkronisasi penjadwalan pembelajaran belum berlangsung.

Selanjutnya evaluasi dilakukan untuk melihat sejauh mana kontinuitas kegiatan pembelajaran teaching factory. Berdasarkan angket yang diberikan kepada guru sebagai responden, menunjukan persentase skor untuk indikator pembelajaran berjalan berkelanjutan memperolah hasil sebesar 75\%. Hasil pemeriksaan angket menunjukan bahwa dari empat orang guru yang diberikan pertanyaan, tiga orang mengatakan kegiatan pembelajaran teaching factory telah berjalan secaraberkelanjutan, sedangkan satu orang guru mengatakan belum berjalan secara berkelanjutan. Setelah peneliti menelusuri lebih lanjut melalui wawancara dan observasi secara langsung diperoleh informasi bahwa, secara umum kegiatan teaching factory telah berjalan dengan baik. Hampir setiap hari kecuali hari libur, kegiatan produksi terus berlangsung, terutama untuk produksi fish jelly (produk olahan ikan siap saji).

Sedangkan untuk produksi Surimi (lumatan daging Ikan), sampai saat ini kontinuitas belum berjalan secara maksimal. Hal tersebut dikarenakan, ketergantungan produksi terhadap ketersediaan bahan baku (ikan) yang dipasok oleh mitra usaha. Apabila mitra kerja (pemasok) dalam waktu-waktu tertentu tidak mengantar bahan baku maka terpaksa kegiatan produksi olahan Surimi tidak berjalan.

Selanjutnya, hasil penilaian terhadap aspek penjadwalan tersebut dinilai kembali menggunakan rubrik penilaian hasil evaluasi untuk memperoleh hasil keseluruhan. Berdasarkan penilaian tersebut diperoleh skor total 12 dari skor ideal 15, dengan persentase sebesar $80 \%$, atau mendapat kategori penilaian baik.

\section{Kinerja Guru}

Instrumen yang digunakan untuk mengukur kinerja guru dilakukan melalui studi dokumentasi terhadap tiga indikator, yakni: (a) pembuatan Rencana Pelaksanaan Pembelajaran (RPP), (b) penyusunan modul pembelajaran, dan (c) penyiapan instrumen penilaian. Evaluasi terhadap ketersediaan RPP, penyusunan modul dan penyiapan instrumen penilaian dilakukan melalui studi dokumentasi. Peneliti telah menyiapkan instrumen checklist untuk mengukur kelayakan dokumen tersebut.

Hasil penelusuran terhadap komponenkomponen di atas secara umum telah sesuai, RPP telah relevan dengan tujuan pembelajaran, menyusun dan menyiapkan modul serta menyusun alat penilaian. Berdasarkan hasil studi dokumentasi, diperoleh hasil bahwa dokumen RPP telah tersedia.
RPP untuk pembelajaran teaching factory terdapat di dalam mata pelajaran pengolahan modern dengan standar kompetensi pembuatan diversifikasi produk perikanan dan kompetensi dasar, melakukan pembuatan surimi, nugget ikan, bakso ikan, kaki naga, ekado, siomay, dan siomay. Selanjutnya, berdasarkan hasil penilaian cheklist terhadap seluruh komponen RPP tersebut, diperoleh yang memuaskan dengan skor 13 dari total skor ideal 13 atau mendapat persentase sebesar $100 \%$. Hal tersebut menunjukan bahwa, dari seluruh komponen RPP yang diharapkan tercantum dalam RPP telah terpenuhi seluruhnya.

Selanjutnya studi dokumentasi dilakukan terhadap ketersediaan modul pembelajaran. Hasil evaluasi menunjukan bahwa modul pembelajaran teaching factory telah tersedia.

Terakhir, evaluasi terhadap indikator penyiapan instrumen penilaian. Berdasarkan hasil studi dokumentasi diperoleh informasi bahwa instrumen penilaian telah tersedia. Berdasarkan penilaian tersebut diperoleh skor total 13 dari skor ideal 15 , dengan perolehan persentase sebesar $87 \%$, atau mendapat kategori penilaian sangat baik.

\section{Aktivitas Guru}

Aktivitas guru dalam pembelajaran teaching factory meliputi semua bentuk kegiatan yang dilakukan guru saat melaksanakan kegiatan pembelajaran. Instrumen yang digunakan untuk mengukur aktivitas guru dilakukan melalui pedoman observasi. Peneliti melakukan pengamatan langsung terhadap aktivitas guru dalam proses pembelajaran yang meliputi tiga hal, yaitu: (a) kegiatan pembukan, (b) inti, dan (c) penutup. Aktivitas pengamatan dilakukan terhadap empat orang guru dan selanjutnya peneliti melakukan checklist dari setiap aktivitas guru tersebut sesuai standar yang telah ditetapkan.

Secara umum, aktivitas guru saat pembelajaran sudah memadai. Terlihat dalam kinerja masing-masing guru ketika mengajar sudah baik. Hanya saja masih ada beberapa unsur yang tidak dilakukan oleh para guru saat kegiatan pendahuluan, seperti menyiapkan kondisi pembelajaran agar peserta didik terlibat baik secara psikis maupun fisik dan mengajukan pertanyaan berkenaan dengan pengetahuan peserta didik.

Setelah dilakukan penilaian menggunakan rubrik, aspek aktivitas guru memperoleh skor 12 dari skor ideal 15, dengan perolehan persentase sebesar $80 \%$, dan mendapat kategori penilaian baik.

\section{Aktivitas Peserta Didik}

Aktivitas peserta didik dapat dianalisis dari beberapa indikator yang terdiri dari: (a) pemahaman, 
(b) keterampilan, (c) antusias, (d) percaya diri, (e) disiplin waktu, (f) kerja sama, (g) tanggung jawab, dan (h) kerja tuntas. Data tentang aktivitas peserta didik dihimpun dengan memberikan angket kepada peserta didik sekaligus melakukan pengamatan di lapangan saat kegiatan pembelajaran berlangsung.

Berdasarkan perolehan skor aspek aktivitas peserta didik, maka dapat disimpulkan bahwa aspek aktivitas telah berjalan sangat memadai. Skor yang diperoleh 34 dari skor ideal yang diharapkan 40, atau memperoleh persentase maksimlal sebesar $85 \%$. Dengan perolehan persentase tersebut maka aspek kesiapan peserta didik mendapat kategori penilaian sangat baik.

Hasil penilaian terhadap seluruh aspek yang terdapat di dalam komponen proses kemudian disatukan untuk memperoleh hasil evaluasi komponen proses secara keseluruhan. Berdasarkan analisis data terhadap empat aspek yang terdapat di dalam komponen proses maka dapat disimpulkan bahwa komponen proses program pembelajaran teaching factory di SUPM Negeri Tegal secara keseluruhan memperoleh persentase sebesar $83 \%$ atau mendapat kategori penilaian sangat baik.

\section{Komponen Produk (Product)}

Evaluasi komponen produk dilakukan untuk melihat hasil yang dicapai baik selama maupun pada akhir pelaksanaan program yang bersangkutan. Komponen produk dalam penelitian ini dianalisis dari beberapa aspek yang terdiri dari: (a) hasil belajar, (b) hasil produksi, dan (c) pencitraan. Pada aspek hasil belajar indikator keberhasilan yang digunakan adalah ketika lebih dari 70\% peserta didik dinyatakan kompeten. Kemudian aspek hasil produksi, indikator yang digunakan adalah ketika hasil produksi berhasil layak jual dan diterima pasar. Sedangkan aspek yang terakhir, yakni pencitraan, indikator yang digunakan adalah apresiasi positif dari masyarakat baik berupa penghargaan, kunjungan instansi, maupun liputan oleh media.

\section{Hasil Belajar}

Evaluasi hasil belajar dilakukan menggunakan instrumen uji kompetensi keahlian, sedangkan materi uji yang diberikan adalah Good Manufacturing Product (GMP) atau mengikuti prosedur kerja menjaga praktek pengolahan yang baik. Nilai akhir uji kompetensi merupakan materi gabungan dari nilai teori dan praktek, dengan nilai perbandingan teori 30\% dan nilai praktek $70 \%$.

Berdasarkan hasil uji kompetensi yang telah dilakukan menunjukan bahwa dari 33 peserta didik, seluruhnya mendapat nilai lebih dari 7,00 yang menjadi kriteria keberhasilan. Dengan demikian, dapat dikatakan $100 \%$ peserta didik yang mengikuti program pembelajaran teaching factory ini dinyatakan berkompeten.

Berdasarkan perolehan hasil tersebut maka selanjutnya dilakukan penilaian menggunakan rubrik penilaian hasil evaluasi untuk mengetahui kategori penilaian yang diperoleh. Hasilnya mendapat skor 5 dari skor ideal 5 dengan persentase sebesar 100\%, sehingga masuk dalam kategori penilaian baik.

\section{Hasil Produksi}

Berdasarkan hasil observasi di lapangan, diketahui hasil produksi teaching factory pengolahan ikan di SUPM Negeri Tegal terdiri dari dua jenis produk yakni fish jelly (produk olahan ikan siap saji) dan Surimi (lumatan daging Ikan). Beberapa produk fish jelly yang telah dihasilkan antara lain: bakso ikan, keong mas, ekado, siomay, otak-otak original, otakotak pedas, fish stick, kaki naga. Sedangkan produk surimi merupakan produk olahan setengah jadi berupa lumatan daging ikan yang telah mengalami proses pemotongan kepala dan pembuangan isi perut dan leaching yang berulang-ulang. Produk ini berguna sebagai bahan baku pembutan produk diversifikasi olahan ikan seperti bakso, nuget, sosis, otak-otak, dan lain-lain.

Berdasarkan hasil observasi terhadap hasil produksi dan wawancara yang telah dilakukan dengan guru diperoleh penjelasan bahwa hasil produksi kegiatan teaching factory SUPM Negeri Tegal telah layak jual. Hal tersebut dibuktikan dengan telah diterimanya hasil produksi tersebut oleh pasar. Wilayah pemasaran untuk produk fish jelly (produk olahan ikan siap saji) selama ini meliputi Kota Tegal dan sekitarnya. Sedangkan produksi surimi di kirim ke Cibitung, Kabupaten Kendal, dan Jakarta. Selanjutnya, setelah dilakukan penilaian menggunakan rubrik penilaian hasil evaluasi, diperoleh skor 4 dari skor ideal 5 , sehingga memperoleh persentase sebesar $80 \%$ atau mendapat kategori penilaian baik.

\section{PENUTUP}

Berdasarkan hasil evaluasi ditemukan kecenderungan bahwa pelaksanaan program pembelajaran teaching factory di SUPM Negeri Tegal secara umum telah berjalan dengan baik, meskipun masih terdapat beberapa hal yang perlu dibenahi. Secara lebih rinci kesimpulan hasil evaluasi dapat diuraikan sebagai berikut.

Pertama, komponen konteks (context). Evaluasi komponen konteks terdiri dari dua aspek yaitu: 
(a) landasan formal, dan (b) kebijakan kepala sekolah. Hasil evaluasi terhadap aspek landasan formal menunjukan bahwa pelaksanaan program pembelajaran teaching factory telah didukung dan selaras dengan peraturan-peraturan perundangan yang ada. Selanjutnya, aspek kebijakan kepala sekolah secara umum mendapatkan kategori penilaian baik, namun masih terdapat indikator yang perlu dilengkapi, yakni petunjuk teknis pelaksanaan program pembelajaran teaching factory.

Kedua, komponen masukan (input). Evaluasi komponen masukan terdiri lima aspek, yaitu: (a) perencanaan kegiatan teaching factory, (b) kesiapan guru, (c) kesiapan peserta didik, (d) sarana prasarana, dan (e) pembiayaan. Hasil evaluasi terhadap aspek Perencanaan terlihat kecenderungan yang belum optimal. Terhadap tiga indikator di dalam aspek perencanaan kegiatan teaching factory, dua di antaranya tidak tersedia, yakni Rencana Kerja Jangka Menengah/5th (RKJM) dan Rencana Kerja Jangka Panjang (Masterplan).

Selanjutnya, hasil penilaian aspek Kesiapan Guru secara umum masuk dalam kategori penilaian baik. Namun demikian masih terdapat nilai yang sangat rendah di dalam salah satu indikatornya, yakni Pelatihan Pengelolaan Pembelajaran teaching factory. Untuk aspek kesiapan peserta didik diperoleh hasil yang sangat baik. Sedangkan untuk aspek sarana dan prasarana, berdasarkan hasil inventory chekclist, observasi dan wawancara terlihat masih terdapat beberapa kekurangan ataupun kerusakan yang harus diperbaiki, namun secara umum masih dalam kondisi baik. Terakhir, evaluasi terhadap aspek pembiayaan hanya masuk dalam kategori cukup. Secara umum ,ketersediaan pembiayaan masih memungkinkan untuk berjalannya program namun dalam kondisi yang terbatas.

Ketiga, komponen proses (process). Ada empat aspek yang dievaluasi dalam komponen proses, yakni: (a) penjadwalan, (b) kinerja guru, (c) aktivitas guru, dan (d) aktivitas peserta didik. Pada aspek penjadwalan pembelajaran teaching factory masih dalam kategori baik. Namun demikian, di dalam aspek penjadwalan masih terdapat indikator dengan nilai yang rendah, terutama terhadap sinkronisasi penjadwalan pembelajaran teaching factory dengan pembelajaran di kelas.

Selanjutnya, hasil evaluasi terhadap aspek kinerja guru menunjukan hasil yang sangat baik. Untuk aspek aktivitas guru, secara umum aktivitas sudah memadai. Terlihat dari interaksi dan kinerja masing-masing guru ketika mengajar sudah cukup mumpuni. Sedangkan hasil evaluasi terhadap aspek aktivitas peserta didik diperoleh hasil yang sangat baik.

Keempat, komponen produk (product). Komponen produk dalam penelitian ini dianalisis dari beberapa aspek yang terdiri dari (a) hasil belajar, hasil produksi, dan (c) pencitraan. Pada aspek hasil belajar menunjukan perolehan hasil evaluasi yang sangat baik. Hasil perolehan penilaian menunjukan bahwa dari semua peserta didik yang mengikuti program pembelajaran teaching factory dinyatakan berkompeten.

Selanjutnya, evaluasi terhadap aspek hasil produksi terlihat sudah cukup baik, namun demikian tampilan kemasan perlu ditingkatkan agar lebih menarik. Terakhir, untuk aspek pencitraan terlihat belum memperlihatkan hasil yang optimal. Hanya satu yang telah berlangsung, yakni kunjungan dari berbagai instansi, sedangkan penghargaan dan liputan media ada.

\section{Saran}

Sejalan dengan kesimpulan di atas, selanjutnya peneliti memberikan rekomendasi sebagai berikut. Pertama, rekomendasi terkait komponen konteks: Sekolah perlu menyusun petunjuk teknis pelaksanaan teaching factory agar tergambar secara jelas alur mekanisme dalam pelaksanaan kegiatan.

Kedua, beberapa rekomendasi terkait komponen masukan antara lain perlu disusun Rencana Kerja Jangka Menengah/5 th (RKJM) dan Rencana Kerja Jangka Panjang (masterplan), sehingga kegiatan dapat berjalan terencana, sistematis dan berkesinambungan. Selain itu, aspek sarana dan prasarana masih perlu ditingkatkan, beberapa yang mendesak seperti pengadaan cold storage (mesin penyimpan produk), contack plate freezer (mesin pembeku), dan penambahan leaching tank (mesin pencucian daging).

Ketiga, rekomendasi terkait komponen proses yaitu, mengatur ulang sinkronisasi penjadwalan pembelajaran teaching factory dan pembelajaran di kelas dengan menerapkan sistem pembagian waktu pagi dan sore. Waktu pagi dapat dialokasikan untuk pembelajaran di kelas dan waktu sore dapat dialokasikan untuk pembelajaran teaching factory. Sistem ini akan mengatasi kelemahan sistem piket yang mengharuskan sejumlah peserta didik meninggalkan pembelajaran di kelas saat bertugas di unit produksi atau teaching factory.

Keempat, beberapa rekomendasi terkait komponen produk antara lain perlu upgrade desain kemasan produk-produk fish jelly yang lebih menarik dan menjual. Selain itu, perlu aktif mengikuti berbagai acara, seperti pameran, lomba dan pengenalan kepada 
media agar pelaksanaan pembelajaran Teaching factory di SUPM Negeri Tegal lebih dikenal sekaligus mengangkat citra sekolah.

\section{DAFTAR PUSTAKA}

Arifin, Z. (2013). Evaluasi pembelajaran, prinsip teknik dan prosedur. Bandung: PT. Remaja Rosdakarya.

Arikunto, S.,\& Jabar, C. A. (2004). Evaluasi program pendidikan,pedoman teoritis praktis bagi praktisi pendidikan. Jakarta: PT. Bumi Aksara.

Fitzpatrick, Jody L James, Sander R dan Blaine B Worthen. (2004). Program Evaluation, Alternative Approaches and Guidelines Third Edition. Boston: Person Education.
Heinich, Molenda, R. M., Russel, J. D.,\& Smaldino, S. E. (1996). Instructional technology and media for learning egiht edition. New Jersey: Pearson Merrill Prentice Hall Inc.

Kuswantoro, A. (2014). Teaching factory rencana dan nilai entrepreneurship. Yogyakarta: Graha Ilmu.

Miles, M.B \& A.M. Huberman. (1994). An expendeed sourcebook qualitative data analysis. London: Sage Publications.

Moleong, L. J. (2012). Metodologi penelitian kualtiatif. Jakarta: PT. Remaja Rosdakarya.

Suparman, A. (2012). Desain instruksional modern. Jakarta: Erlangga, 2012.

Sudjana, D. (2008). Evaluasi program pendidikan luar sekolah. Bandung: PT. Remaja Rosdakarya, 2008.

Tayibnapis, F. Y. (2000). Evaluasi program. Jakarta: PT. Rineka Cipta, 2000.

Widyoko, E. P. (2013). Evaluasi program pembelajaran panduan praktis bagi pendidik dan calon pendidik. Jogjakarta: Pustaka Pelajar. 